\title{
A new dinosaur tracksite with small footprints in the Urbión Group (Cameros Basin, Lower Cretaceous, La Rioja, Spain)
}

\author{
I. Díaz-Martínez ${ }^{1,2 *}$, E. García-Ortiz³, F. Pérez-Lorente ${ }^{1}$ \\ ${ }^{1}$ Universidad de La Rioja, c/Madre de Dios 51-53, 26006 Logroño (La Rioja), Spain \\ ${ }^{2}$ CONICET - Instituto de Investigación en Paleobiología y Geología, Universidad Nacional de Río Negro, c/ General Roca \\ 1242, 8332 Fisque Menuco-General Roca (Río Negro), Argentina. \\ ${ }^{3}$ Universidad de León. Área de Paleontología. Dpto. Geografía y Geología. Facultad de Filosofía y Letras. Campus de \\ Vegazana, s/n. 24071, León, Spain \\ e-mail addresses: inaportu@hotmail.com (I.D.M., *corresponding author); cloessense@hotmail.com (E.G.O); felix.perez@unirioja.es (F.P.L.)
}

Received: 15 January 2014 / Accepted: 18 December 2014 / Available online: 25 March 2015

\begin{abstract}
A new dinosaur tracksite (La Rueda) with ten small tridactyl footprints (the length ranges between 9 and $15 \mathrm{~cm}$ ) from the Urbión Group (Cameros Basin, Lower Cretaceous, La Rioja, Spain) is described. The footprints are approximately as long as wide and have high divarication angles between digits II-IV $\left(\sim 80^{\circ}\right)$, some pad impressions on each digit, claw marks, a medial notch and a circular heel pad impression. They are here classified as indeterminate ornithopod footprints and contribute to the increase in the dinosaur ichnodiversity of the Urbión Group. Small dinosaur footprints are scarce in the worldwide fossil record. In the Urbión Group, large dinosaur tracks are much more frequent than small ones. This scarcity could be explained as ecological biases (dearth of small individuals in an area). Nevertheless, the number of small footprints in the Urbión Group is instead the product of by preservation biases (coarse grain sediments and fluvial erosive bases) and the weathering and erosion processes (brittle nature of the rock) that affect especially to small tracks than large ones identified in this Group.
\end{abstract}

Keywords: Small footprints, Dinosaurs, Urbión Group, Lower Cretaceous, Spain

\begin{abstract}
Resumen
En el Grupo Urbión (Cuenca de Cameros, Cretácico Inferior, La Rioja, España) se ha identificado un nuevo yacimiento (La Rueda) con diez icnitas pequeñas tridáctilas de dinosaurio, cuya longitud varía entre 9 y $15 \mathrm{~cm}$. Las huellas son aproximadamente tan largas como anchas y tienen una alta divergencia entre los dedos II-IV, varias impresiones de almohadillas en cada dedo, marcas de uñas, una escotadura en la parte medial y una impresión del talón circular. Se han identificado como icnitas ornitópodas indeterminadas y contribuyen a incrementar la icnodiversidad del Grupo Urbión. Las icnitas de dinosaurio pequeñas son escasas en el registro fósil mundial. Se han descrito más icnitas de dinosaurios grandes que pequeñas en el Grupo Urbión. Esta escasez podría ser debida a sesgos ecológicos. Sin embargo, el número de icnitas pequeñas está condicionado por los sesgos preservacionales y los procesos de meteorización y erosión identificados en este Grupo.
\end{abstract}

Palabras clave: Huellas pequeñas, Dinosaurios, Grupo Urbión, Cretácico Inferior, España

\section{Introduction}

The Cameros Basin is a privileged place to study dinosaur footprints. It is estimated to contain more than 250 tracksites, although the total number depends on if the tracksites with a single footprint, the missing ones, the inventoried, cataloged or considered BIC (Asset of Cultural Interest in Spanish) are included (Pérez-Lorente, 2003). The Lower Cretaceous of the Cameros Basin is traditionally divided into five lithostratigraphic groups: Tera, Oncala, Urbión, Enciso and Oliván. All the units except for the Oliván Group have yielded dinosaur footprints. The tracksites are distributed in the provinces of Burgos, Soria and La Rioja, in beds whose age ranges from Late Jurassic to Early Cretaceous (Tithonian-Albian).

The La Rueda tracksite (LRU) is a new outcrop from La Rioja with ten small (length $<15 \mathrm{~cm}$ ) tridactyl footprints. Leonardi (1981) suggested that there are just a few tracksites described with small dinosaur footprints in the world fossil record. The same occurs in the Cameros Basin when comparing them to the total number of tracksites. Three tracksites with small footprints 
have been cited in the Oncala Group (Fuentes, 1996; Fuentes and Meijide, 1998; Pascual-Arribas and Hernández-Medrano, 2011), two in the Urbión Group (Torcida et al., 2006; this study) and five in the Enciso Group (Casanovas et al., 1991, 1992, 1993, 1997; Moratalla-García, 1993).

Small dinosaur footprints have been associated with small species or juveniles of large species (Leonardi, 1981). The scarcity of this kind of footprints has been explained by the dearth of small individuals (small species or juveniles) in an area or due to rapid growth rates for juveniles track makers (e.g., Leonardi, 1981; Lockley, 1994; Padian et al., 2001; Kim et al., 2012). Nevertheless, other authors have suggested that the preservation biases and weathering and erosional processes should be taken into account to explain this scarcity (Henderson, 2006; Kim et al., 2012).

The main objective of this work is to describe in detail a new dinosaur tracksite, La Rueda (LRU), and its ichnotaxonomical and palaeoecological implications. Moreover, the scarcity of small dinosaur footprints in the Urbión Group is analyzed.

\section{Geographic and geologic location}

The La Rueda tracksite is situated in northern central Spain, in the Province of La Rioja, close to the village of Laguna de Cameros (Fig. 1). The coordinates of the site are: (UTM) $\mathrm{X}=$ $537.557 ; \mathrm{Y}=4.668 .755$, in the ETRS89 datum. It occurs within the Cameros Basin, a high-subsidence basin of the Iberian Rift System that underwent several tectonic phases in the Mesozoic and Cenozoic periods (Mas et al., 2002; 2011). During the Late Jurassic and Early Cretaceous, the basin was a fluviolacustrine zone in which siliciclastic and carbonate sediments were deposited (Mas et al., 2002; Doublet, 2004).
The footprints are preserved on a small silty sandstone slab with very thin lamination of the Unit 26 "red clays, siltstones and sandstones" of the upper part of the Urbión Group (Ramírez Merino et al., 1990). This group, that corresponds with the depositional sequences of Cameros Basin 4, 5, 6 and lower part of 7 (Mas et al., 2011), consists of fluvial deposits interbedded with channels formed by fine-grained conglomerates and sands (Clemente, 2011).

Geologically, the upper part of Urbión Group shows differences in the east as compared to the west of the Cameros Basin. In the eastern sector (La Rioja and Soria provinces), where is located La Rueda tracksite, the upper part of the Urbión Group evolves towards the Enciso Group (see Fig. 2). Nevertheless, the Enciso Group is absent in the western section (Burgos province). The upper part of Urbión Group in the West (Abejar Formation) is the lateral equivalent of the Enciso Group and therefore, youngest than the eastern sector (cf. Mas et al., 2004; Fig.2). On the basis of charophytes, Doublet (2004) proposed that the age of the eastern section of Urbión Group is basal Valanginian/ late Valanginian to early Barremian/early Aptian. As La Rueda tracksite is in the upper part of the Urbión Group (Ramírez Merino et al., 1990), the age of the new site may be early Barremian-early Aptian.

\section{Material and methods}

This work studied ten footprints that are arranged in a trackway of four tracks and three paired tracks (Fig. 3). The footprints are designated according to previous convention (e.g., Casanovas et al., 1989; Pérez-Lorente, 2003) as follows: first, the tracksite identification; second, the trackway; and third, the footprint.

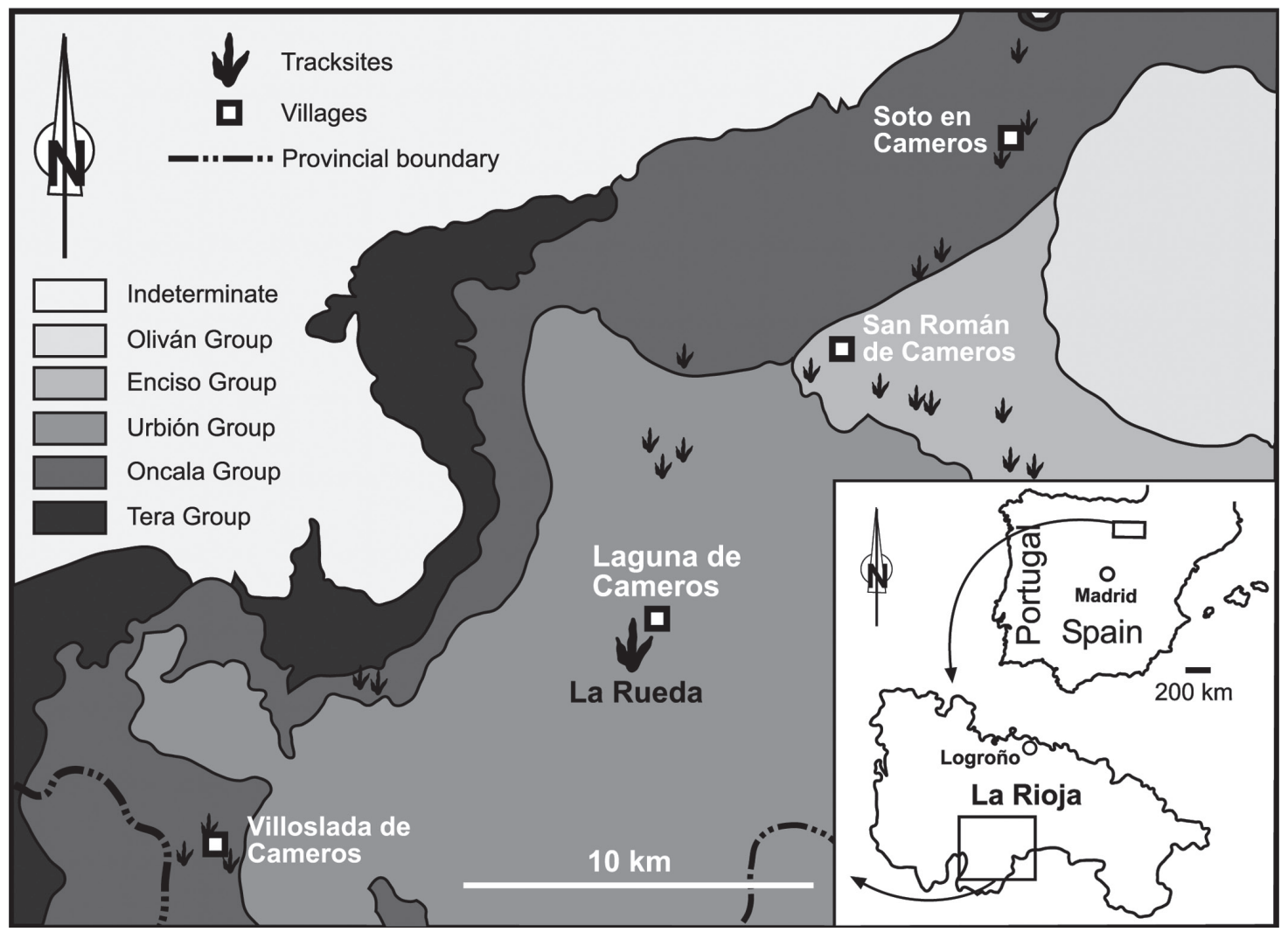

Fig. 1.- Geographical and geological location of the La Rueda tracksite. 


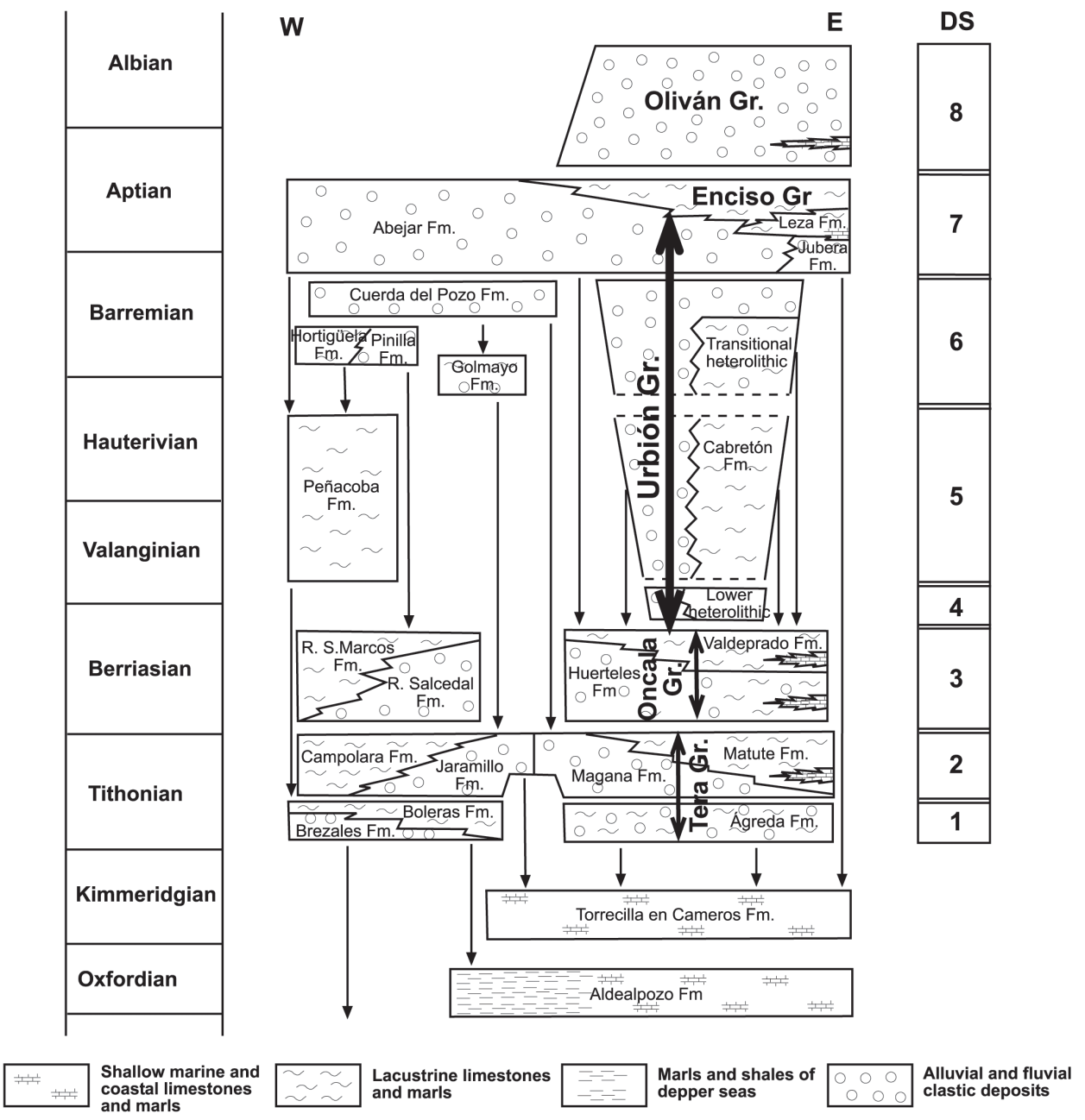

Fig. 2.- Simplified chronostratigraphic chart of the Cameros Basin (modified of Mas et al., 2004 and González-Acebrón et al., 2007). (DS) depositional sequences.

For instance, LRU4.1 is the first footprint of trackway number 4 of La Rueda tracksite.

The measurements (Table 1) and the nomenclature used in this study are mainly based on previous works (Haubold, 1971; Weems, 1992; Pérez-Lorente, 2001). The measurements taken were: footprint length (FL), footprint width (FW), pace length (PL), stride length (SL), trackway deviation (TD), external trackway width (eTW), pace angulation (ANG), footprint rotation (FR), digit divarication angles $\left(\mathrm{II}^{\wedge} \mathrm{III}, \mathrm{III}^{\wedge} \mathrm{IV}\right.$, $\left.\mathrm{II}^{\wedge} \mathrm{IV}\right)$, and the extension of the digit III beyond a line drawn across the tip of the digits II and IV, measured down the axis of digit III (TE). The hip height $(\mathrm{H})$ was estimated with the Thulborn (1990) allometric formula for small ornithopods, and the speed was calculated using the Alexander (1976) formula (V1) and the Demathieu (1986) formula (V2).

All parameters (Table 1) are given and compared in cm, except ANG, FR, II^III and III ${ }^{\wedge}$ V that are calculated in degrees, and the speed in $\mathrm{km} / \mathrm{h}$. The parameters have been measured directly in the field or in the laboratory from drawings using AutoCAD software.

Photogrammetric models (Falkingham, 2012) (Fig. 4) were obtained using Agisoft PhotoScan software and were generated for two tridactyl tracks (LRU2.2 and LRU3.2) with the aim of distinguishing the contour line of the impressions, which are not easily discernible using traditional methods (mainly because the tracks are very shallow and the surface is irregular). Photogrammetric models were also imported into Meshlab and Paraview softwares in which depth and contour lines analysis were produced.

\section{Results}

In the La Rueda tracksite, ten small and very shallow (approximately $10 \mathrm{~mm}$ ) footprints have been observed, all of them arranged in a trackway of four tracks and three paired footprints (Figs. 3, 4). They are preserved as shallow concave epireliefs. The footprints are tridactyl, mesaxonic, and approximately as long as wide (the length ranges between 9 and $15 \mathrm{~cm}$ and the width between 12 and $14 \mathrm{~cm}$ ) (Table 1). Digit III projection (sensu Weems, 1992) is from 5.1 to 6.5, which means that the footprint length is on the order of twice the projection $(\mathrm{FL}=2 \mathrm{TE})$.

The footprints of pair LRU1 and part of trackway LRU2 (LRU2.1, LRU2.3 and LRU2.4) are poorly defined and therefore it is not possible take some measures. The pair LRU1 could be part of the trackway LRU2 or the pair LRU4. Nevertheless, in LRU2.2 and in the pairs LRU3 and LRU4 it is possible to 


\begin{tabular}{|c|c|c|c|c|c|c|c|c|c|c|c|c|c|c|c|c|c|c|c|}
\hline & FL & FW & TD & eTW & PL & SL & ANG & FR & II $^{\wedge} \mathbf{I I I}$ & III^IV & II $^{\wedge} \mathbf{I V}$ & $\mathbf{H}$ & SL/H & V1 & V2 & $($ FL-FW)/FW & TD/FW & SL/FL & TE \\
\hline mean & 13 & 14 & - & & 41 & & & & 50 & 38 & 88 & 63 & & & & -0.07 & - & - & 5.8 \\
\hline LRU3.1 & 13 & 12 & - & & & & & & 52 & 39 & 91 & 63 & & & & 0.09 & - & - & 5.9 \\
\hline mean & 11 & 12 & - & & & & & & 36 & 52 & 88 & 53 & & & & -0.13 & - & - & 5.9 \\
\hline LRU2.4 & 12 & 12 & - & & 49 & & & & 14 & 29 & 43 & 58 & & & & 0 & - & - & - \\
\hline LRU2.3 & 14 & 12 & 4 & & 44 & 93 & 162 & 1 & 25 & 35 & 60 & 69 & 1.5 & 4.4 & 3.3 & 0.17 & 0.33 & 6.6 & 5.1 \\
\hline mean & 13 & 12 & 3 & 24 & 42 & 85 & 163 & -2 & 28 & 32 & 60 & 63 & 1.4 & 3.9 & 3.1 & 0.08 & 0.25 & 6.3 & 5.3 \\
\hline LRU1.2 & - & - & - & - & 51 & - & - & - & - & - & - & - & - & - & - & - & - & - & - \\
\hline LRU1.1 & - & - & - & - & - & - & - & - & - & - & - & - & - & - & - & - & - & - & - \\
\hline mean & - & - & - & - & 51 & - & - & - & - & - & - & - & - & - & - & - & - & - & - \\
\hline
\end{tabular}

Table 1.- Measurements of the footprints from La Rueda (La Rioja, Spain). Footprint length (FL), footprint width (FW), trackway deviation (TD), external trackway width (eTW), pace length (PL), stride length (SL), pace angulation (ANG), footprint rotation (FR), digit divarication angles (II^III, III^^IV, II^IV), height (H), speed using the formula of Alexander (1976) (V1), speed using the formula of Demathieu (1986) (V2) and digit III projection (TE). All parameters are given and compared in cm, except ANG, FR, II^III, III^IV and II^IV that are calculated in degrees and V1 and $\mathrm{V} 2$ in $\mathrm{km} / \mathrm{h}$.

follow the footprint contour line and they present the same general morphology. These footprints are characterized by having longer than wide digit impressions, some pad impressions in each digit, and in some of them an acuminate distal end. The divarication among the digits II-III and III-IV is highly variable. Nonetheless, the angle between digits II-IV ranges from $80^{\circ}$ to $96^{\circ}$. The footprints are roughly symmetrical. The heel impression is outgoing and well-marked with a medial notch behind the proximal part of digit II. In almost all footprints, a circular heel pad that is deeper than the rest of the track is located in the back of the IV toe.

The trackway LRU2 is very narrow and the footprints have inward rotation. The hind limbs average height is between 47 and $57 \mathrm{~cm}$, and according to the relationship SL/FL (6.3) the hind limbs would have been gracile (see parameters in PérezLorente, 2001). The speed average is low, ranges from 3.5 to 4.4 $\mathrm{km} / \mathrm{h}$ in V1 and from 2.8 to $3.3 \mathrm{~km} / \mathrm{h}$ in V2 (other biomorphic and morphometric measures are presented in Table 1).

The trackway and the pairs have opposite orientations: LRU1, LRU4 and LRU2 heading south, while LRU3 going north (Figs. $3 \mathrm{~A}, \mathrm{~B})$.

The footprint LRU4.2 shows a millimeter-thick layer within digit II and IV distal ends. This layer is above the study surface and it is not deformed, therefore it is interpreted as an overtrack. The footprints of La Rueda tracksite are very shallow (see Fig. 4). We consider all as true tracks because they have pad impressions, claw marks and are covered by an overtrack, but they are not elite tracks due to its preservation (not well-preserved). They might be somewhat eroded because they are close to a river (Fig. $3 \mathrm{~A})$ that covers the lower part of the tracksite at flood-stage.

\section{Discussion}

\subsection{Ichnotaxonomy}

La Rueda footprints are mainly characterized by high divarication between digits II-IV, some pad impressions in each digit, claw marks, a medial notch and a circular heel pad impression (Figs. 3, 4, 5A-E). In addition, they are roughly symmetrical, approximately as long as wide and the length is about twice the digit III projection. Some of these features have been identified as belonging to theropod (including avian) and small ornithopod ichnotaxa.

Most of the theropod ichnotaxa have claw marks and some pad impressions in each digit. Nevertheless, theropod tracks have generally less divarication than the La Rueda footprints and generally they are asymmetrical (cf. Thulborn, 1990; Pérez-Lorente and Romero-Molina, 2001). In a broad sense, the avian ichnotaxa have high divarication, but they differ essentially from those of La Rueda in having more slender digits and a less projected digit III (cf. De Valais and Melchor, 2008). La Rueda footprints are similar (roughly symmetrical, similar position, and the shape of the heel impression and claw marks) (Figs. 5A-E) to some small ornithopod ichnotaxa such as Anomoepus Hitchcock, 1848 (Figs. 5F-G), Moyenisauropus Ellenberger, 1970 (Fig. 5H), and Dineichnus Lockley, Santos, Meyer and Hunt, 1998 (Fig. 5I). Dineichnus has no pad impressions in each digit or a medial notch. Moyenisauropus and Anomoepus differ from them in the divarication between the digits II-IV and in the projection of the digit III, which are higher in the La Rueda footprints, but the other general features are similar (cf. Thulbon, 1990). Both ichnotaxa are characterized for its resting traces, with metatarsal and hallux marks and the presence of pentadactyl manus prints, but also occurs in the form of multiple pesonly tracks (Olsen and Rainforth, 2003; Belvedere et al., 2011). Therefore, taking into account the morphological features and the preservation of the La Rueda footprints (very shallow and not well-preserved footprints) we have assigned them to indeterminate ornithopod footprints.

\subsection{Palaeoecology}

García-Ortiz and Pérez-Lorente (2014) analyzed the gregarious behavior based on Cretaceous dinosaur footprints from $\mathrm{La}$ Rioja. They summarized several important criteria for inferring gregarious behaviour from tracksites. For example, multiple parallel trackways of the same morphotype in the same stratigraphic surface, and same footprint depth (Lockley, 1991; 

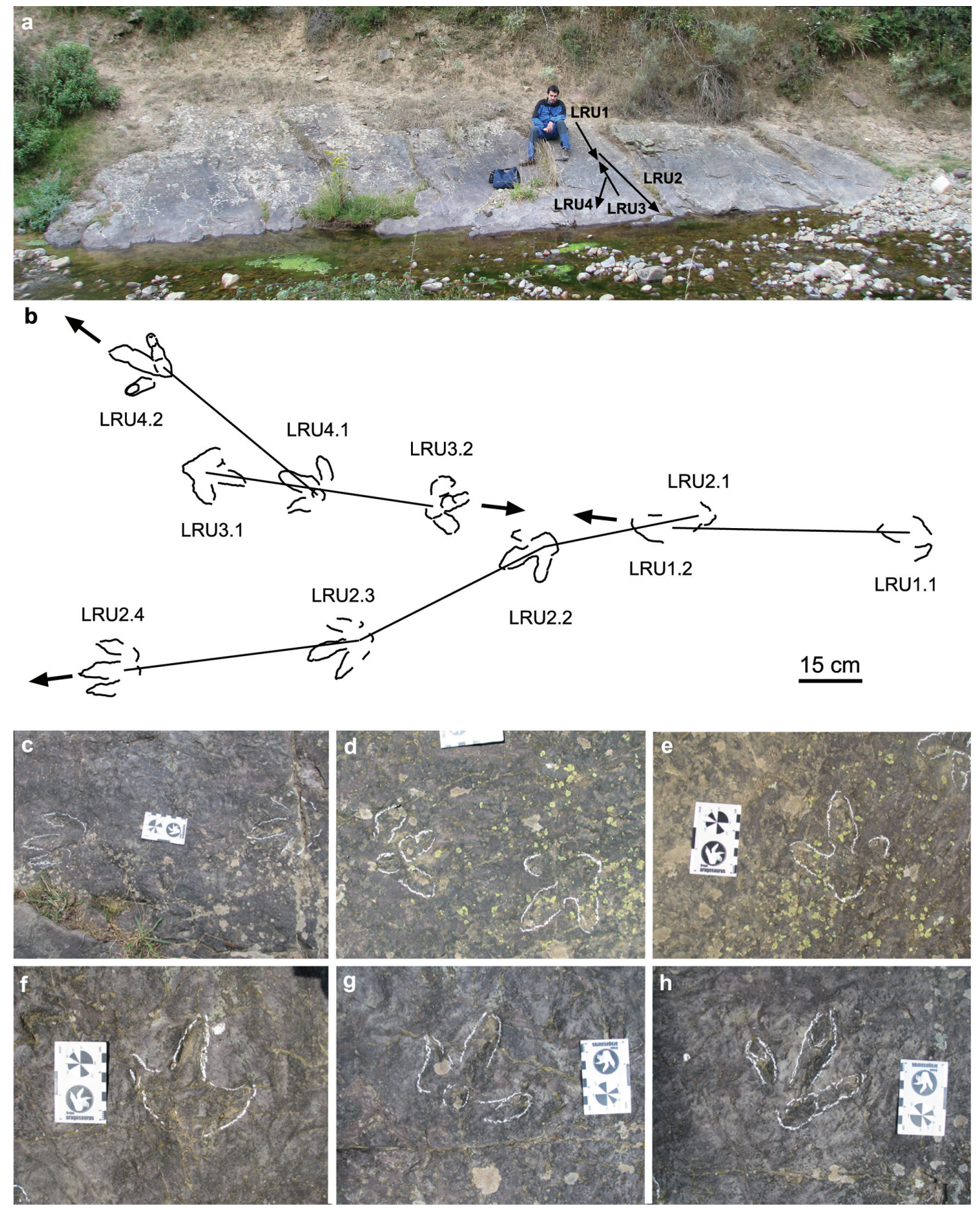

Fig. 3.- a) Perspective of La Rueda tracksite. b) Sketch map. Picture of footprints c) LRU2.3 and LRU2.4, d) LRU2.2 and LRU3.2, e) LRU2.2, f) LRU3.1, g) LRU4.1 and h) LRU4.2.

Lockley and Matsukawa, 1999) could be interpreted as several dinosaur individuals of the same taxon moving at the same place at the same time. Furthermore, García-Ortiz and Pérez-Lorente (2014) noted that the opposite orientations in the trackways can be produced in environments with topographic barriers, as occurs in actual ecosystems such as lakesides and riversides. The La Rueda tracksite shares all the above mentioned features (same footprint type, similar depth, parallel trackways and opposite orientations). Although there are few footprints that are preserved in a small slab $(2 \times 1 \mathrm{~m})$, these data could indicate dinosaur gregariousness.

Small dinosaur footprints, as those of the La Rueda tracksite, have traditionally been interpreted as footprints of juveniles or as a small species, but there are not clear criteria to differentiate 

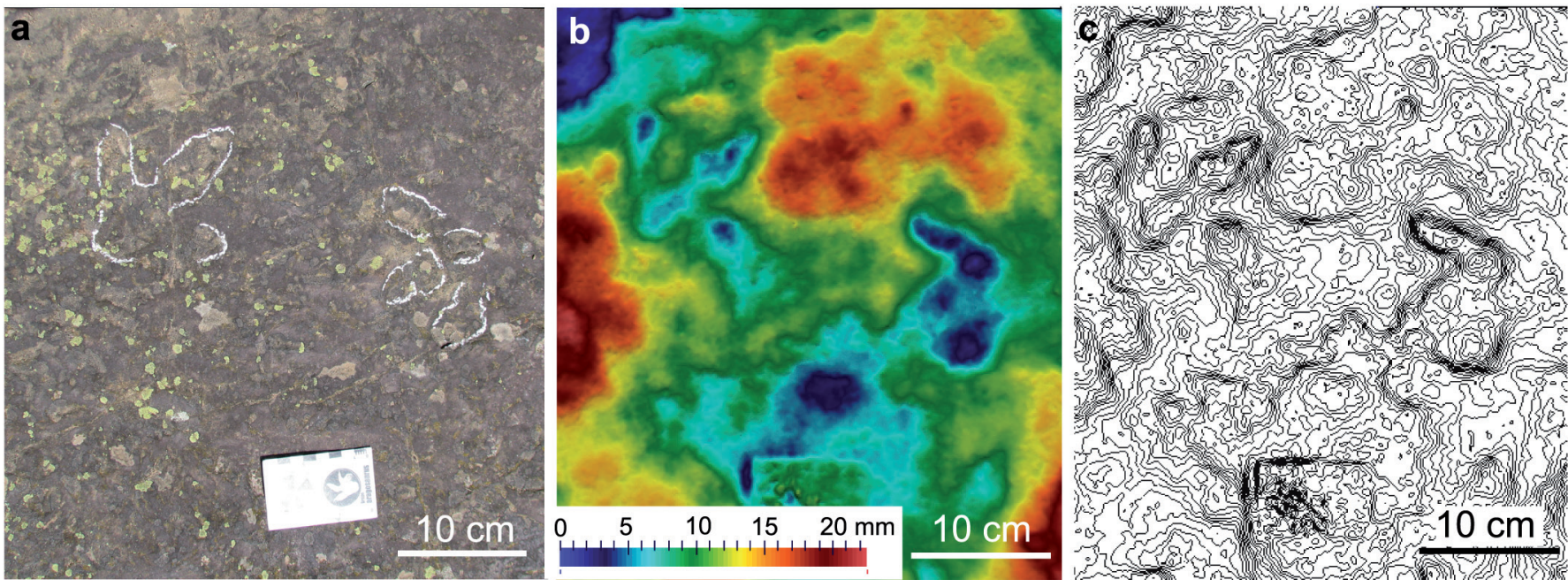

Fig. 4.- a) Picture, b) photogrammetric 3D depth analysis model, and c) contour lines map with $0.5 \mathrm{~cm}$ of equidistance of footprints LRU2.2 (left) and LRU3.2 (right).

them. Small ornithopod footprints are generally related to basal ornithischians and even to basal ornithopods (Thulborn, 1990; Lockley et al., 2009) in which the adults are relatively small in size. In the Urbión Group, there are no larger in size footprints with similar characters. These data suggest that the track makers of the La Rueda footprints were likely adults, but we do not have sufficient information to confirm this interpretation.

In the Urbión Group, theropod (including avian), sauropod and ornithopod footprints have been described (see Torcida, 1996; Pérez-Lorente, 2002, 2003; Hernández-Medrano et al., 2005-2006, and references therein) (Figs. 6A-H). Most of the footprints are larger than $15 \mathrm{~cm}$, except for several footprints of the Costalomo (Torcida et al., 2006) and La Rueda (this study) tracksites. Costalomo tracksite is located in the Pinilla de los Moros Formation (upper Hauterivian-lower Barremian, Burgos Province). The small footprints of Costalomo range from 13 to $18 \mathrm{~cm}$ in length (Figs. 6F-H) and they have been classified as theropod footprints (trackway CSL-K), including avian footprints (trackway CLS-L and isolated footprints CLS-52, CLS-61 and CLS-79) (Torcida et al., 2006). In the La Rueda tracksite, the footprints range from 9 to $15 \mathrm{~cm}$ in length, representing the smallest footprints found to date at the Urbión Group. In addition, the footprints of this tracksite, classified as indeterminate ornithopod footprints, which together with the other morphotypes described in previous works (large and small theropod, large sauropod, and large ornithopod footprints; see Torcida, 1996; Pérez-Lorente, 2002, 2003; Hernández-Medrano et al., 2005-2006, Díaz-Martínez, 2013, and references therein) increasing our knowledge of the dinosaur ichnodiversity presents in the fluvial deposits of Urbión Group.

The small dinosaur footprints are scarce in the Urbión Group. The scarcity of small dinosaur footprints has been explained in other tracksites (see Leonardi, 1981) by three main factors: ecological biases, preservation biases, and weathering-erosional processes.

Leonardi (1981) noted that there were few small dinosaur footprints in the fossil record. He explained the absence of this kind of tracks due to the dearth of small individuals (small species or juveniles) in an area. Kim et al. (2012) suggested that the local absence of small tracks produced by juveniles of large dinosaurs might represent rapid growth rates for juvenile trackmakers (e.g., Lockley, 1994; Padian et al., 2001). Both hypotheses explain the absence of small footprints because of ecological biases against them. On the other hand, Falkingham et al. (2011) and Kim et al. (2012) proposed an alternative and complementary interpretation for the absence of small footprints at tracksites that takes preservation bias into consideration. Kim et al. (2012) affirmed that in suitable facies, like fine grained lake margin sediments, large number of small footprints can be found. Nevertheless, in more coarse grain sediments, the footprints would be very poorly preserved, showing no detailed anatomical features (Kim et al., 2012). Falkingham et al. (2011) proposed the 'Goldilocks' effect, and discussed the different preservations among tracks formed in homogeneous cohesive substrates with and without the presence of a firmer subsurface layer, and their relationship with the size of the trackmaker. In homogeneous cohesive substrates, only a narrow range of loads produce tracks (small animals failed to indent the substrate, and larger animals would be unable to traverse the area), but if a firm subsurface layer is assumed, a more complete assemblage is possible, though there is a strong bias towards larger, heavier animals (Falkingham et al., 2011). Finally, Henderson (2006) noted that the small and shallowly impressed tracks were the most susceptible to the effects of modern weathering and erosion processes.

The scarcity of small footprints in the Urbión Group could be explained as the sum of the above three factors. In this group, both preservation biases from weathering and erosional processes have been recognized. The Urbión Group is composed of fluvial deposits formed by fine-grained conglomerates and sandstones (Clemente, 2011). Pérez-Lorente (2002) considered that the grain size of the best-preserved layers (sandstones and conglomerates) is coarse and this fact makes it difficult to find footprints. Moreover, he suggested that the sandstones and conglomerates of the Urbión Group have erosive bases that destroyed the tracks that could have been in the top of the silt layers. According to Pérez-Lorente (2002), the Urbión Group 
a

b
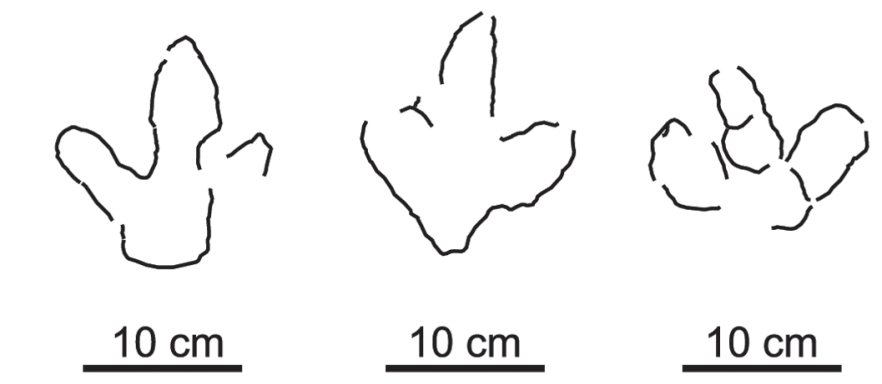

d<smiles>CCCCCCCCC</smiles>
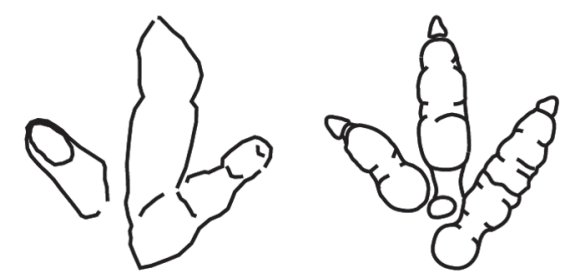

9
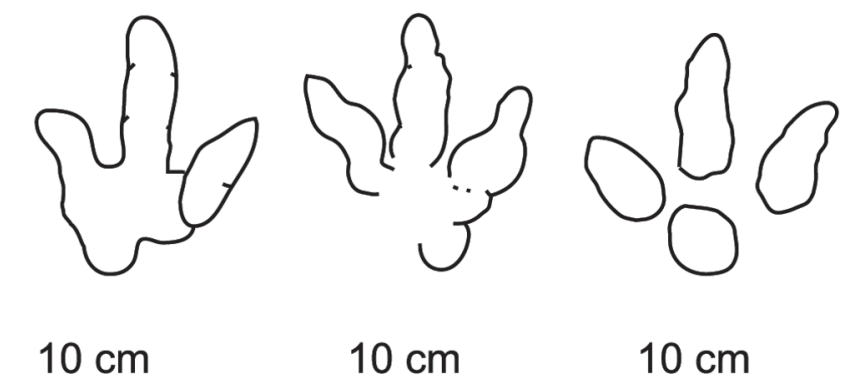

$10 \mathrm{~cm}$ a

b

C
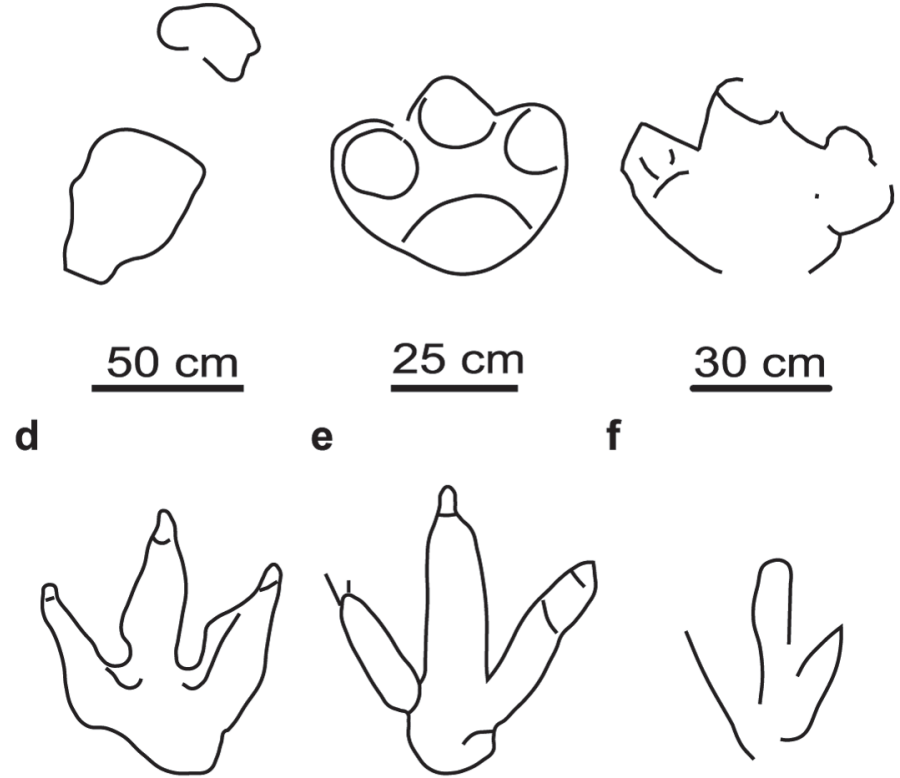

$25 \mathrm{~cm}$

$30 \mathrm{~cm}$
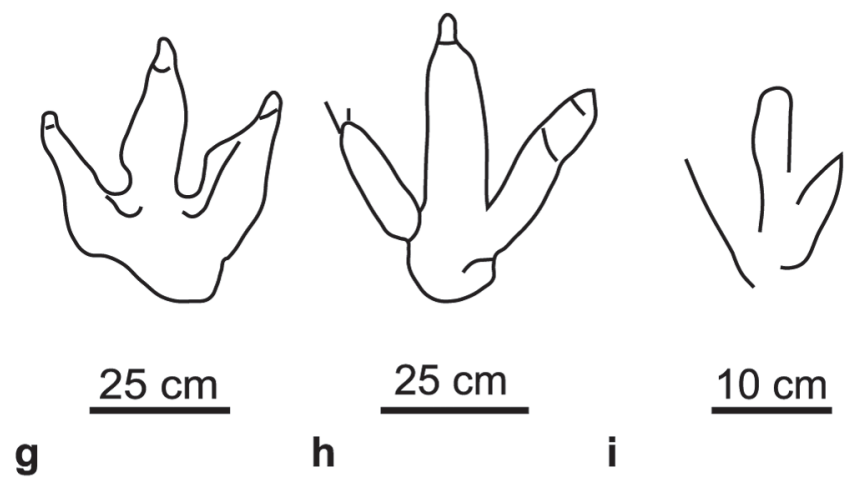

$10 \mathrm{~cm}$
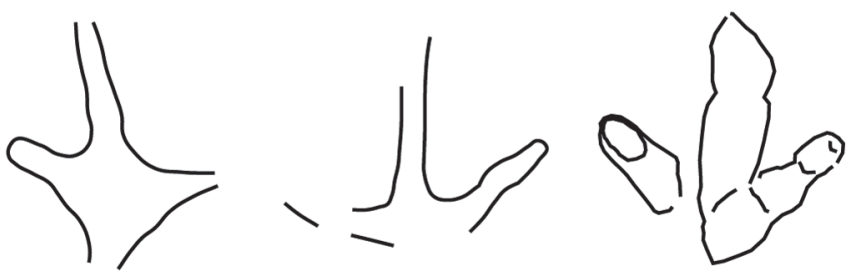

$10 \mathrm{~cm}$

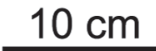

$10 \mathrm{~cm}$

Fig. 6.- Dinosaur ichnodiversity of the Urbión Group. Outline drawings of: a) sauropod track from the Costalomo tracksite (redrawn from Torcida et al., 2006); large ornithopod fooprints from b) the El Frontal tracksite (redrawn from Moratalla et al., 1994), and c) the Los Chopos tracksite (redrawn from Díaz-Martínez et al., 2007); d-f) theropod footprints from the Costalomo tracksite (redrawn from Torcida et al., 2006); g-h) avian footprints from the Costalomo tracksite (redrawn from Torcida et al., 2006); and i) small ornithopod footprint from $\mathrm{La}$ Rueda (this study).

is the lithostratigraphic unit of the Cameros Basin that contains the majority of the outcrops. Nevertheless, in the Urbión Group only 17 dinosaur tracksites have been described (nine in La Rioja Province, five in Burgos Province and three in Soria Province) (sensu Pérez-Lorente, 2003; Díaz-Martínez, 2013); this number is considerably less than the more than two hundred known within the Oncala and Enciso groups. Ansorena et al. (2007-2008) suggested that the number of footprints in the Urbión Group rocks should be abundant, even given the few and small outcrops. This disparity is due to the brittle nature of the rock and its clastic composition, deformation and metamorphism that makes them extremely fragile (Pérez-Lorente, 2002). On the other hand, large footprints are more often described in

the Urbión Group (e.g., Moratalla et al., 1992; Torcida, 1996; Pérez-Lorente, 2002, 2003; Hernández-Medrano et al., 20052006; Torcida et al., 2006; Díaz-Martínez et al., 2007; Ansorena et al., 2007-2008) than small footprints (Torcida et al., 2006; this study). This difference could be due to an ecological bias, as explained above. Nevertheless, it is difficult to identify this bias at the tracksites because the number of small footprints preserved in comparison to large ones is influenced directly by the other two factors. The preservation biases and the weathering and erosion processes limit the interpretation of the palaeoecology, principally the abundance and paleodiversity/ichnodiversity, of the Urbión Group. The richness of large theropod, sauropod and ornithopod tracks compared to the scarcity of small tracks not 
reflects a greater abundance of large trackmakers in these facies. This abundance represents the morphotypes that were better preserved after the biases discussed previously. Thus, the study of the small footprints of the La Rueda tracksite is important because it provides new data to complete the knowledge of the ichnodiversity in this group.

\section{Conclusions}

The footprints from the La Rueda tracksite are the smallest found to date at the Urbión Group (Lower Cretaceous of Cameros Basin, Spain). All of them, characterized by being tridactyl, as long as wide, with high divarication between digits II-IV, some pad impressions in each digit, claw marks, a medial notch and a circular heel pad impression, are classified as indeterminate ornithopod footprints. They are different from other ichnotypes described in the Urbión Group, and thus increase the dinosaur ichnodiversity in this unit.

The scarcity of small dinosaur footprints in the fossil record has been explained as the sum of ecological biases, preservation biases and weathering and erosional processes. In the Urbión Group, more large dinosaur tracks than small ones have been described. This scarcity could be explained by ecological biases. Nevertheless, preservation biases (coarse grain sediments and fluvial erosive bases) and weathering and present-day erosional processes (the brittle nature of the rock) have been identified in this group. The relationship between large and small footprints is a product of the number of footprints preserved as result of the last two factors. Therefore, the study of the La Rueda tracksite is important because it provides new information about the palaeoecology (ichnodiversity) of the Urbión Group.

\section{Acknowledgements}

We thank to the editors of this special volume and to the organization members of VI Jornadas Internacionales sobre Paleontología de Dinosaurios y su Entorno held in the summer of 2013 in Salas de los Infantes (Spain). We also thank Xabier Pereda-Suberbiola for their comments on an early version of the manuscript, and Dr. José Ignacio Ruiz-Omeñaca and Dr. Peter L. Falkingham for their comments and suggestions. Research of I.D.-M. is supported by the group IT834-13 of the Basque Government and the project CGL2013-47521-P of the Spanish Ministerio de Economía y Competitividad (MINECO), and Postdoctoral grant from the Ministerio de Ciencia, Tecnología e Innovación Productiva Consejo Nacional de Investigaciones Científicas y Técnicas from Argentina.

\section{References}

Alexander, R.M. (1976): Estimates of speed of dinosaurs. Nature 261, 129-130. doi: 10.1038/261129a0

Ansorena, P., Díaz-Martínez, I., Pérez-Lorente, F. (2007-2008): Mina Victoria (Navajún) y Valdeperillo (Cornago). Nuevos yacimientos de icnitas de dinosaurio en el Grupo de Urbión (Cuenca de Cameros. La Rioja. España). Zubía 25-26, 75-96.

Belvedere, M., Dyke, G., Hadri, M., Ishigaki, S. (2011): The oldest evidence for birds in Northern Gondwana? Small tridactyl footprints from the Middle Jurassic of Msemrir (Morocco). Gondwana Research 19, 542-549. doi: 10.1016/j.gr.2010.08.004

Casanovas, M.L., Fernández Ortega, A., Pérez-Lorente, F., Santafé, J.V. (1989): Huellas de dinosaurio de La Rioja. Yacimientos de Valdecevillo, La Senoba y de la Virgen del Campo. Instituto de Estudios Riojanos (IER), Logroño. Ciencias de la Tierra 12, 190 p.

Casanovas, M.L., Fernández, A., Pérez-Lorente, F., Santafé, J.V. (1991): Dinosaurios coelúridos gregarios en el yacimiento de Valdevajes ( $\mathrm{La}$ Rioja, España). Revista Española de Paleontología 6, 177-189.

Casanovas, M.L., Ezquerra, R., Pérez-Lorente, F., Santafé, J.V. (1992): Revisión del yacimiento "Icnitas 3" de huellas de dinosaurio (Enciso, La Rioja, España). Zubía 10, 31-44.

Casanovas, M.L., Ezquerra, R., Fernández, A., Pérez-Lorente, F., Santafé, J.V., Torcida, F. (1993): Icnitas de dinosaurios. Yacimientos de Navalsaz, Las Mortajeras, Peñaportillo, Malvaciervo y la Era del Peladillo 2 (La Rioja, España). Zubía Monográfico 5, 9-133.

Casanovas, M.L., Fernández, A., Pérez-Lorente, F., Santafé, J.V., Torcida, F. (1997): Pisadas de ornitópodos, terópodos y saurópodos en la Era del Peladillo 5 (La Rioja, España). Zubia 15, 229-246.

Clemente, P. (2011): Review of the Upper Jurassic-Lower Cretaceous stratigraphy in Western Cameros Basin, Northern Spain. Revista de la Sociedad Geológica de España 23, 101-143.

Demathieu, G. (1986): Nouvelles recherches sur la vitesse des vertébrés, auteurs de traces fossiles. Geobios 19, 327-333. doi: 10.1016/S00166995(86)80021-3

De Valais, S., Melchor, R.N. (2008): Ichnotaxonomy of bird-like footprints: an example from the Late Triassic-Early Jurassic of Northwestern Argentina. Journal of Vertebrate Paleontology 28, 145-159. doi: 10.1671/0272-4634(2008)28[145:IOBFAE]2.0.CO;2

Díaz-Martínez, I. (2013): Icnitas de dinosaurios bípedos de La Rioja (Cuenca de Cameros, Cretácico Inferior): icnotaxonomía y aplicación paleobiológica. Unpublished Doctoral Thesis, Universidad de La Rioja, Logroño, 2 vols., 632 p. + 253 p.

Díaz-Martínez, I., García-Ortiz de Landaluce, E., Ibisate, R., PérezLorente, F. (2007): Nuevas aportaciones al registro paleoicnológico en Cabezón de Cameros (La Rioja. España). Geogaceta 42, 87-90.

Doublet, S. (2004): Contrôles tectonique et climatique de l'enregistrement stratigraphique dans un bassin continental de rift: le bassin de Cameros (Jurassique supérieur-Crétacé inférieur) provinces de Soria-La Rioja, Espagne. Unpublished Doctoral Thesis, Université de Bourgogne, Dijon, 497 p.

Ellenberger, P. (1970) : Les niveaux paléontologiques de première apparition des mammifères primordiaux en Afrique du Sud et leur ichnologie : établissement de zones stratigraphiques détaillées dans le Stormberg du Lesotho (Afrique du Sud) (Trias supérieur à Jurassique). In: S.H. Haughton (ed.), Proceedings and Papers Second Gondwana Symposium. Council for Scientific and Industrial Research, Pretoria, pp. 343-370.

Falkingham, P.L. (2012) : Acquisition of high resolution three-dimensional models using free, open-source, photogrammetric software. Palaeontologia Electronica 15(1), 1T:15p.

Falkingham, P.L., Bates, K.T., Margetts, L., Manning, P.L. (2011): The 'Goldilocks' effect: preservation bias in vertebrate track assemblages. Journal of the Royal Society Interface, 8, 1142-1154. doi: 10.1098/ rsif. 2010.0634

Fuentes, C. (1996): Primeras huellas de aves en el Weald de Soria (España). Nuevo icnogénero, Archaeornithipus y nueva icnoespecie A. meijidei. Estudios Geológicos 52, 63-75. doi: 10.3989/egeol.96521-2254

Fuentes, C., Meijide, M. (1998): Icnitas de dinosaurios terópodos en el Weald de Soria (España). Nuevo icnogénero Kalohipus. Estudios Geológicos 54, 147-152. doi: 10.3989/egeol.98543-4213 
García-Ortiz, E., Pérez-Lorente, F. (2014): Palaeoecological inferences about dinosaur gregarious behaviour based on the study of tracksites from the La Rioja area in the Cameros Basin (Lower Cretaceous), Spain. Journal of Iberian Geology 40, 113-127. doi: 10.5209/rev JIGE.2014.v40.n1.44091

Gierliński, G. (1991): New dinosaur ichnotaxa from the Early Jurassic of the Holy Cross Mountains, Poland. Palaeogeography, Palaeoclimatology, Palaeoecology 85, 137-148. doi: 10.1016/00310182(91)90030-U

González-Acebrón, L., Arribas, J., Mas, R. (2007): Provenance of fluvial sandstones at the start of late Jurassic-Early Cretaceous rifting in the Cameros Basin (N. Spain). Sedimentary Geology 202, 138-157. doi: 10.1016/j.sedgeo.2007.05.008

Haubold, H. (1971): Ichnia Amphibiorum et Reptiliorum fossilium. In: O. Kuhn (ed.), Handbuch der Paläoherpetologie 18. Gustav Fischer Verlag, Stuttgart, $123 \mathrm{p}$.

Henderson, D.M. (2006): Simulated weathering of dinosaur tracks and the implications for their characterization. Canadian Journal of Earth Sciences 43, 691-704. doi: 10.1139/e06-024

Hernández-Medrano, N., Pascual Arribas, C., Latorre Macarrón, P., Sanz Pérez, E. (2005-2006): Contribución de los yacimientos de icnitas sorianos al registro general de Cameros. Zubia 23-24, 79-120.

Hitchcock, E. (1848): An attempt to discriminate and describe the animals that made the fossil footmarks of the United States, and especially of New England. Memoirs of the American Academy of Arts and Sciences 3, 129-256.

Kim, K.S., Lockley, M.G., Kim, J.Y., Seo, S.J. (2012): The smallest dinosaur tracks in the world: occurrences and significance of Minisauripus from East Asia. Ichnos 19, 66-74. doi: 10.1080/10420940.2012.664052

Leonardi, G. (1981): Ichnological data on the rarity of young in northeast Brazil dinosaurian populations. Anais da Academia Brasileira de Ciências 53, 345-346.

Lockley, M.G. (1991): Tracking Dinosaurs: A new Look at an Ancient World. Cambridge University Press, Cambridge, 238 p.

Lockley, M.G. (1994): Dinosaur ontogeny and population structure: Interpretations and speculations based on fossil footprints. In: K. Carpenter, K.F. Hirsch, J.R. Horner (eds), Dinosaur eggs and babies. Cambridge University Press, Cambridge, pp. 347-365.

Lockley, M.G., Matsukawa, M. (1999): Some observations on trackway evidence for gregarious behavior among small bipedal dinosaurs. Palaeogeography, Palaeoclimatology, Palaeoecology 150, 25-31. doi: 10.1016/S0031-0182(99)00005-X

Lockley, M.G, Santos, V.F. dos, Meyer, C., Hunt, A. (1998): A new dinosaur tracksite in the Morrison Formation, boundary Butte, southeastern Utah. Modern Geology 23, 317-330.

Lockley, M.G., McCrea, R. T., Matsukawa, M. (2009): Ichnological evidence for small quadrupedal ornithischians from the basal Cretaceous of SE Asia and North America: implications for a global radiation. Geological Society London Special Publications 315, 255-269. doi: 10.1144/SP315.18

Mas, R., Benito, I., Arribas, J., Serrano, A., Guimerá, J., Alonso, A., Alonso-Azcarate, J. (2002): La Cuenca de Cameros: Desde la extensión finijurásica-eocretácica a la inversión terciaria - Implicaciones en la exploración de hidrocarburos. Zubía Monográfico 14, 9-64.

Mas, R., García, A, Salas, R., Meléndez, A., Alonso, A., Aurell, M., Bádenas, B., Benito, M.I., Carenas, B., García- Hidalgo, J.F., Gil,
J., Segura, M. (2004): Segunda fase de rifting: Jurásico SuperiorCretácico Inferior. In: J. Vera (ed), Geología de España. Sociedad Geológica de España - Instituto Geológico y Minero de España, Madrid, pp. 503-509.

Mas, R., Benito, M.I., Arribas, J., Alonso, A., Arribas, M.E., Lohmann, K.C., González-Acebrón, L., Hernán, J., Quijada, E., Suárez, P., Omodeo, S. (2011): Evolution of an intra-plate rift basin: the Latest Jurassic-Early Cretaceous Cameros Basin (Northwest Iberian Ranges, North Spain). In: C. Arenas, L. Pomar, F. Colombo (eds), Post-Meeting Field trips Guidebook, 28th IAS Meeting. Geo-Guías 8, Sociedad Geológica de España, Zaragoza, pp. 117-154.

Moratalla García, J.J. (1993): Restos indirectos de dinosaurios del registro español: Paleoicnología de la Cuenca de Cameros (Jurásico Superior-Cretácico Inferior) y Paleoología del Cretácico Superior. Unpublished Doctoral Thesis, Universidad Complutense de Madrid, Madrid, 727 p.

Moratalla, J.J., Sanz, J.L., Jiménez, S., Lockley, M.G. (1992): A quadrupedal ornithopod trackway from the Lower Cretaceous of La Rioja (Spain): inferences on gait and hand structure. Journal of Vertebrate Paleontology 12, 150-157. doi: 10.1080/02724634.1992.10011445

Olsen, P.E., Rainforth, E.C. (2003): The Early Jurassic ornithischian dinosaurian ichnogenus Anomoepus. In: P.M. LeTourneau, P.E. Olsen (eds.), The Great Rift Valleys of Pangea in Eastern North America: volume 2, Sedimentology, Stratigraphy, and Paleontology. Columbia University Press, New York, pp. 314-367.

Padian, K., Ricqlès, A., Horner, J.R. (2001): Dinosaurian growth rates and bird origins. Nature 412, 405-408. doi: 10.1038/35086500

Pascual-Arribas, C., Hernández-Medrano, N. (2011): Posibles huellas de crías de terópodo en el yacimiento de Valdehijuelos (Soria, España). Studia geologica salmanticensia 47, 77-110.

Pérez-Lorente, F. (2001): Paleoicnología. Los dinosaurios y sus huellas en La Rioja. Fundación Patrimonio Paleontológico de La Rioja, Logroño, $227 \mathrm{p}$.

Pérez-Lorente, F. (2002): La distribución de yacimientos y tipos de huellas de dinosaurio en la Cuenca de Cameros (La Rioja, Burgos, Soria, España). Zubía Monográfico 14, 191-210.

Pérez-Lorente, F. (2003): Icnitas de dinosaurios del Cretácico en España. In: F. Pérez-Lorente (ed.), Dinosaurios y otros reptiles mesozoicos de España, Instituto de Estudios Riojanos (IER), Logroño. Ciencias de la Tierra 26, 49-108.

Pérez-Lorente, F., Romero Molina, M.M. (2001): Icnitas terópodas del Cretácico inferior de La Rioja (España). Zubía 19, 115-138.

Ramírez Merino, J.I., Olivé, A., Hernández Samaniego, A., Álvaro, M. (1990): Hoja geológica núm. 241 (Anguiano). Mapa Geológico de España E. 1:50.000. $2^{\mathrm{a}}$ serie, I.G.M.E., Madrid.

Thulborn, T. (1990): Dinosaur tracks. Chapman and Hall, London, 410 p. Torcida, F. (1996): Registro de dinosaurios en el sureste de la provincia de Burgos. Zubia 14, 89-104.

Torcida, F., Izquierdo L.A., Huerta, P., Montero, D., Pérez, G., Urién, V. (2006): El yacimiento de icnitas de dinosaurios de Costalomo (Salas de los Infantes, Burgos, España): Nuevos datos. In: Colectivo Arqueológico y Paleontológico de Salas (ed.). Actas III Jornadas Internacionales sobre Paleontología de Dinosaurios y su Entorno, Salas de los Infantes, Burgos, pp. 313-347.

Weems, R.E. (1992): A re-evaluation of the taxonomy of Newark Supergroup saurischian dinosaur tracks, using extensive statistical data from a recently exposed tracksite near Culpeper, Virginia. Virginia Division of Mineral Resources Publication 119, 113-127. 